industry. Brief mention is made of the effects of the European War on ocean rates, tonnage and shipbuilding, of the ship purchase bill, the free shipping clause of the Panama Canal Act of 1912, the registry Act of. 1914, and the La Follette Seaman's Act of 1915.

The text of the book, aside from the introductory chapter, contains a series of stories rather than a connected story of the American merchant marine. It is written in popular style and contains numerous interesting accounts of specified American vessels, captains and shipping enterprises. It does not contain a complete, well organized history of the merchant marine, but gives many accounts of early shipping history which are of interest both to the general reader and to those who wish to make a more detailed study.

G. G. H.

\title{
ACCOUNTING, BUSINESS METHODS, INVESTMENT AND THE EXCHANGE
}

Guenther, Louis. Investment and Speculation (New and Revised Edition). Pp. xi, 289. Price, \$2.00. Chicago: LaSalle Extension Company, 1916.

Under the author's broad definition of the terms "investments" and "speculation," an adequate consideration of the subject of the volume within the space at his dispesal is a physical impossibility. It would seem to have been better policy to have modified the title and restricted the scope of the book to security investments, omitting chapters 3,4 and 5 , dealing with real estate investments. More criticism may be indulged in regarding these three chapters, also, than probably any other three in the book. The statement is made (p. 17) that loans on agricultural lands have proved the most satisfactory. Probably illustrations of individual investors might be furnished where this is correct. On the other hand instances might be cited of particular investors, and large ones, who can show very constant returns and losses of almost no consequence on bonds. The statement is probably intended to apply to investors as a whole, but we have no statistics by which to judge of its accuracy in this respect. On page 18 occurs the statement that "our small interior banks are by far the largest lenders of capital on farm mortgages." The report of Mr. R. L. Cox to the Association of Life Insurance Presidents shows by detailed figures that on June 30, 1914, to quote him, "life insurance companies, collectively, are very much the largest owners of farm mortgages in this country, their holdings exceeding by about 20 per cent the total farm loans held by the 26,765 banks of this country." On page 28 a renewal of a second mortgage on a home at a bonus of $\$ 100$ during the panic of 1907 is stated to be "fairly indicative of the element of risk that capital considers it assumes on such obligations." On page 9 the author considers the laws enacted by various states governing the character of savings bank investments as an example of the "law of averages." It would rather seem to be an instance of the application of selection, similar to the rejection of undesirable applicants by life insurance examiners.

In chapter 6 it is intimated to the reader that the classification of bonds will be according to (1) security, (2) purpose of issue, (3) manner of payment, (4) conditions of redemption, and (5) nature of the issuing company. This manner 
of treatment, probably first adequately worked out in Chamberlain's Principles of Bond Investment, is very satisfactory in results, but after having mentioned the plan the author proceeds to discuss government bonds, railroad bonds, public service corporation bonds, miscellaneous bonds, etc., which is certainly a departure from the above idea. The nature of the bond itself, its security, is the primary factor, generally speaking; the others are secondary. In the chapter on government bonds it is stated, regarding the high interest rates on bonds of certain governments, "This does not at all reflect upon them; it merely fixes the position of their credit in the money capitals of the world." An opinion could hardly be more significantly expressed than by "fixing the position of their credit." No description of the position of a stockholder and the characteristics of a share of stock is given; the chapter dealing with guaranteed stocks contains seven pages devoted to enumerating examples of guaranteed stocks, full descriptions of which are contained in manuals, and which enumeration conveys no principles to the student; no description is given of the various types of preferred stocks.

When chapter 14 is reached all plans of treatment are seemingly thrown aside and chapters on amortization and sinking funds, bonds for women and estates, valuation of bonds, character of an enterprise, science of speculation, efforts to prevent speculation, mystery of a balance sheet, the nature of exchanges, etc., follow each other without any attempt at arrangement.

In brief, this volume seems to suffer from three great defects (1) lack of arrangement of topics, (2) carelessness regarding details and (3) too much attempted in the available space.

It would be unfair not to mention some characteristics worthy of praise. It has the advantage often lacking in books on financial subjects of being capable of comprehension by the average reader. The greater part also has the very good feature of being quite interesting reading, likewise not very common in financial books. The portions treating of the dealings on exchanges are perhaps the best, although here also inaccuracy of statement is sometimes apparent. For instance, in describing contract trading on produce exchanges it is stated (p. 221), "All deliveries must be made on the last day of the month," whereas what is intended to be said is "All deliveries must be made on or before the last day of the month." The statement as it stands conveys the idea that the seller has no option as regards the time of delivery.

Each chapter is accompanied by from four to fourteen questions for the student, generally designed to test his memory and comprehension of the material in the chapter and the book closes with a satisfactory index of seven pages.

\section{University of Pennsylvania.}

ROBERT RIEGEL.

Montgomery, R. H. Auditing: Theory and Practice. (Second edition, revised and enlarged.) Pp. xxvi, 889. Price, \$5.00. New York: The Ronald Press Company, 1916.

The Annals of May 1913 contained a review of the first edition of this work. The revised edition eliminates some portions of the material contained in the first edition, notably reference to English cases and chapters on the Corporation 